\section{ВІДОМОСТІ ПРО АВТОРІВ}

КЛІМОВА Ірина Михайлівна - доцент, доцент кафедри вищої математики Харківського національного автомобільно-дорожнього університету.

Наукові інтереси: теорія, методика та розробка практичних методів навчання (математика).

РИЧКОВА Лариса Володимирівна - кандидат педагогічних наук, доцент, доцент кафедри вищої математики Харківського національного автомобільнодорожнього університету.

Наукові інтереси: теорія, методика та розробка практичних методів навчання (математика).
INFORMATION ABOUT THE AUTHOR

KLIMOVA Irina Mykhailivna - associate professor, associate professor of the department of higher mathematics of Kharkiv National Highway University.

Circle of research interests: theory, methodology and development of practical teaching methods (mathematics).

RYCHKOVA Larisa Volodimirivna - associate professor, associate professor of the department of higher mathematics of Kharkiv National Highway University.

Circle of research interests: theory, methodology and development of practical teaching methods (mathematics).

Стаття надійшла до редакиії 18.11.2019 p

КОНОНЕНКО Сергій Олексійович -

кандидат педагогічних наук, доцент, доцент кафедри теорії і методики технологічної підготовки, охорони праці та безпеки життєдіяльності Центральноукраїнського державного педагогічного університету імені Володимира Винниченка ORCID:https://orcid.org/0000-0001-6637-4994 e-mail:kononenko65@ukr.net

МАНОЙЛЕНКО Наталія Володимирівна кандидат педагогічних наук, доцент, старший викладач кафедри теорії та методики технологічної підготовки, охорони праці та безпеки життєдіяльності

Центральноукраїнського державного педагогічного університету імені Володимира Винниченка ORCID: https://orcid.org/0000-0001-6579-4313 e-mail: nataliaman2017-n@ukr.net

\title{
З ДОСВІДУ ОРГАНІЗАЩІЇ ТА ПРОВЕДЕННЯ ГУРТКОВОЇ РОБОТИ ЗІ СТАРШОКЛАСНИКАМИ ЗАКЛАДІВ ЗАГАЛЬНОЇ СЕРЕДНЬОЇ ОСВІТИ
}

Постановка та обгрунтування актуальності проблеми. Головним завданням освітньої діяльності вчителів завжди була передача знань усіх світових надбань молодому поколінню, для його повноцінного становлення на сучасному етапі існування суспільства та подальшого його розвитку.

Ефективна діяльність суспільного виробництва не можлива без професійно підготовлених фахівців, їх культурно-технічного рівня. Сучасне уявлення про високу кваліфікацію робітника, техніка, інженера науковця, дослідника тісно пов'язане 3 їхнім творчим потенціалом, здатністю до пошуку способів підвищення продуктивності праці.

Для того щоб підготувати освічених фахівців, робітників, інженерів, учених - потрібно з молодого віку виховувати в учнів інтерес до винахідницької діяльності. Розвивати якості, що дають змогу самостійно досліджувати, пізнавати навколишній світ, поліпшувати його, знаходити нові рішення наукових та технічних проблем. Тому ця проблема буде завжди актуальною, так як з нею нерозривно пов'язаний процес існування та розвитку сучасного суспільства в цілому.

Аналіз останніх досліджень і публікацій. Існує багато наукових досліджень щодо організації гурткової роботи та формування науково-технічної творчості старшокласників 3ЗСО (заклади загальної середньої освіти). Розглянуті проблеми в дослідженнях [2; 4; 5; 6; 7], Касперського А.В., Коберника О.М., Сидоренка В.К., довели, що рівень зацікавленості учнів 3 науково-технічної творчості знижується. В першу чергу, потрібно звернути увагу методистів та науковців на діючі програми та підручники 3 фізики, трудового навчання, технологій, креслення, провести їх аналіз та виявити недоліки які відштовхують учнів від зацікавленості наукою і технікою. Крім того, наш побут заполонили найрізноманітніші «гаджети» які при виникненні певної потреби можна просто придбати в магазині, а не виготовити самостійно. Тому, при організації науково-технічної творчості потрібно виокремити як особливий напрям систему підготовки учнів до творчості, особливо в галузі природознавства і техніки. Адже саме цей аспект i визначає рівень соціально-економічного та культурного розвитку держави $[1 ; 8]$.

Відомо, що саме гурткова робота учнів дає найбільш ефективні результати у засвоєнні та поглиблені ними базових та нових знань. Тому, велика увага повинна приділятися саме удосконаленню форм, методів та засобів організації гурткової роботи 3 найбільш прогресивних, 
сучасних наукових та технічних напрямів.

Мета статті - провести аналіз педагогічного досвіду та визначити напрямки удосконалення організації та змісту гурткової роботи учнів 3 радіотехнічного конструювання.

Виклад основного матеріалу дослідження. 3 огляду на мету загальноосвітньої, політехнічної і трудової підготовки старшокласників організація фізико-технічної творчості на уроках і в позакласній роботі має забезпечувати розв'язання таких основних завдань:

- стимулювати пізнавальну активність та інтерес до вивчення відповідних предметів як найважливішої теоретичної основи сучасної техніки;

- сприяти засвоєнню загальнотеоретичних і прикладних знань, формувати науковий світогляд;

- розвивати творчі здібності учнів, що дають змогу успішно набувати i збагачувати досвід творчої діяльності в галузі науки і техніки;

- формувати вміння й навички самостійної пізнавальної і творчої діяльності;

- ознайомлювати школярів 3 основами конструювання і винахідництва, сучасними виробничими процесами (зокрема, процесами розробки і створення нових виробів);

- сприяти набуттю знань, практичних умінь і навичок політехнічного і загально-трудового змісту, а також досвіду їх використання в певних практичних ситуаціях;

- ознайомлювати школярів 3 основними напрямами науково-технічного прогресу, використанням досягнень науки i техніки в промисловості, сільському господарстві і т. ін.;

- розвивати і стимулювати інтерес до техніки, технічної творчості, що дає змогу формувати емоційно-ціннісне ставлення та психологічну готовність до майбутньої трудової діяльності на сучасному виробництві;

- сприяти професійній орієнтації школярів [3].

Робота гуртка 3 радіотехнічного конструювання базується на сам перед на використанні міністерської програми [3]. Проте, при iї реалізації виникає ряд проблем, які потребують від вчителя більш детального осмислення своєї діяльності. Так, наприклад, виготовлення детекторного приймача стає недоцільним у зв'язку 3 відсутністю роботи радіостанцій СХ та ДХ діапазону. Якщо гурток тільки розпочинає свою роботу, то перед ним виникають певні труднощі 3 матеріального та технічного забезпечення. Потрібні різні джерела живлення, генератори, вимірювачі R,C,L та інше. Тому доцільно залучати більш досвідчених учнів до їх виготовлення. Це сприятиме створенню належної матеріально-технічної бази гуртка, та вивчення ними принципу роботи розроблених радіоелектронних пристроїв. На рис. 1. представлено виготовлений гуртківцями блок живлення з регульованою напругою $0-12$ В.

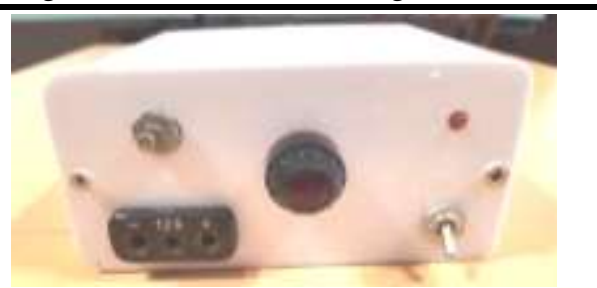

Рис. 1. Зовнішній вигляд джерела живлення

Для повноцінного функціонування гуртка радіотехнічного конструювання необхідно забезпечити організацію робочих місць у відповідності до виконання конкретної технології. А саме: по-перше, для вибору об'єкта праці, технічної інформації, вирішення виникнення нових проблем чи розв'язання поставлених задач потрібне використання комп'ютерної техніки, персонального комп'ютера чи хоча б наявність мобільного телефону 3 доступом в мережу INTERNET. Подруге потрібно створити робочі місця для слюсарних робіт; розмічання, різання, свердління. Робочі місця для паяння та налаштування виготовленого обладнання.

Зрозуміло, що для вирішення поставлених задач необхідне достатнє матеріально-технічне забезпечення яке потребує відповідного фінансування. $Є$ різні шляхи для вирішення цієі проблеми, але викладач повинен розумно та методично обгрунтовано підходити до іiі розв'язання. Так, наприклад, для виконання технологічної операції розмічання потрібно наступне обладнання: лінійка, кутник, штангенциркуль, олівець. Зрозуміло, що в деяких випадках цілком достатньо лише кутника і олівця, які майже завжди $\epsilon$ в учнів. При виготовлені монтажної плати достатньо мати ручну пилку для різання металу та ручний дриль. Для налагодження виготовленого пристрою, особливо для гуртківців першого року навчання, цілком достатньо мати сучасний цифровий мультиметр, який обов'язково повинен бути у викладача. Як джерело живлення, звуковий генератор та осцилограф завжди можна використати шкільні прилади, їх параметри цілком задовольняють вимоги до налаштування простих радіоелектронних пристроїв. Радіодеталі можна випаяти зі старої радіоапаратури.

Важливим питанням є вибір об'єкту праці. Зацікавленість учнів виникає тоді, коли вони виготовляють пристрій за власним задумом. Вчителю лише потрібно узгодити вибір об’ єкту як 3 інтересом гуртківця так і з діючою програмою.

Стосовно вибору необхідних технологій для виготовлення учнями радіотехнічних пристроїв слід зазначити наступне. Одним 3 найпопулярніших способів формування в учнів умінь виконувати монтаж електротехнічних пристроїв $є$ використання макетних плат. Це дає можливість їм здійснювати перші кроки при складанні електричних кіл 3 подальшою можливістю їх налагодження, перевірки та усунення несправностей. Цінним при цьому $є$ те, що в подальшому учень може використати зібрані радіодеталі при монтажі їх на основну плату. Бажано при цьому використовувати нові непаяні 
радіодеталі з не укороченими виводами. На рис. 2. представлено зовнішній вид макетної плати для створення звукового генератора.

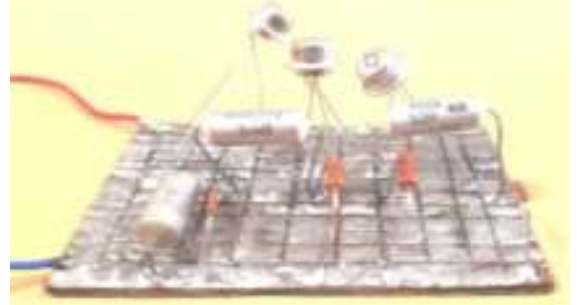

Рис. 2. Зовнішній вид макетної плати звукового генератора

При подальшому виготовлені електронного пристрою, учні переходять до виготовлення монтажної плати. В літературі описано багато різних способів виготовлення друкованих плат, проте як показує досвід для початківців доцільніше використовувати добре відомою технологією вирізання різцем мідних доріжок на фольгованому склотекстоліті. На рис. 3 показано один 3 прикладів монтажу радіодеталей на друкованій платі, розробленій та виготовленій гуртківцями.

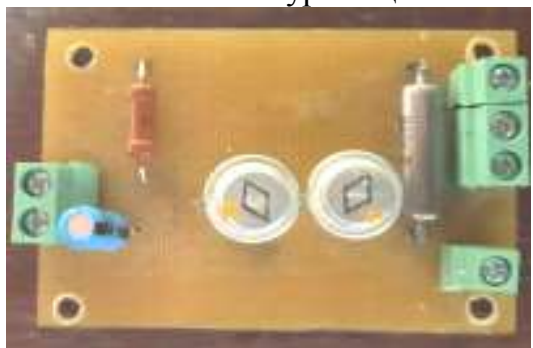

Рис. 3. Зовнішній вид друкованої плати з радіодеталями

Зараз є можливість монтувати радіоелементи на універсальних монтажних платах які можна придбати в торгівельній мережі або замовити через INTERNET-магазини. Ці плати мають більш естетичний вигляд, проте потребують додаткових 3'єднань при пайці радіодеталей. На Рис.4. показано монтаж радіоелементів на цих платах та розміщення їх безпосередньо на шасі.

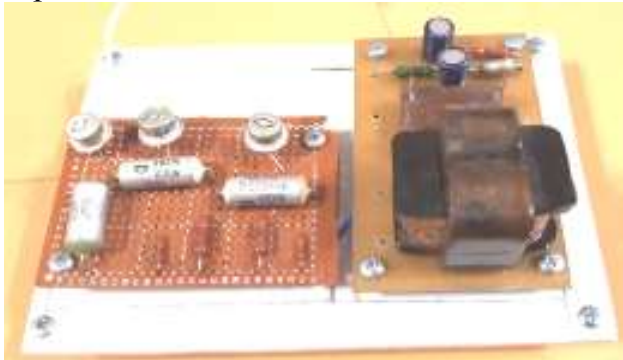

Рис. 4. Монтаж друкованих плат на шасі

На заключному етапі виготовлення пристрою учні приступають до створення корпусу в якому розміщують сам пристрій та органи керування ним. Для цього $є$ багато різноманітних варіантів виготовлення корпусу приладу. Їх можна придбати в радіо магазинах або замовити через Інтернет. Проте, на нашу думку, учням слід рекомендувати самостійне їх виготовлення. Так, нами було запропоновано використати підручні матеріали, а саме пластикові труби для повітря-відведення. Пластик добре i легко піддається обробці, має добрий естетичний вигляд, зручний та надійний в користуванні(рис. 5).

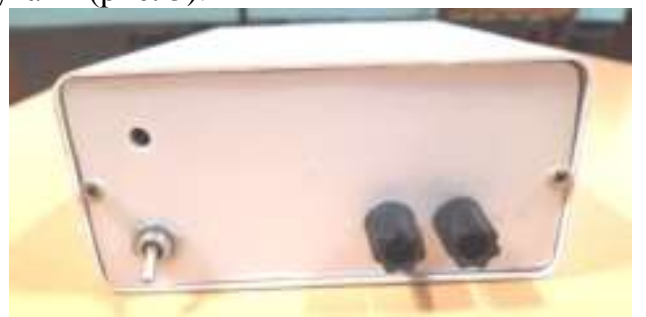

Рис. 5. Зовнішній вигляд пристрою

Висновки та перспективи подальших розвідок напряму. Аналіз педагогічних i методичних досліджень, присвячених проблемам організації й розвитку технічної творчості школярів, вивчення передового педагогічного досвіду роботи шкіл і позашкільних закладів, досвід авторів дають змогу визначити шляхи подальшого вдосконалення позакласної роботи:

- Оптимізація наповнення змісту занять, вибір об'єктів праці які мають зацікавленість учнів.

- Удосконалення форм організації і засобів керівництва діяльністю учнів на позакласних заняттях для ознайомлення 3 особливостями конструкторської та винахідницької діяльності.

- Вирішення питань матеріального забезпечення, створення належних умов для занять гуртків, зміцнення їхньої навчально-матеріальної бази.

\section{СПИСОК ДЖЕРЕЛ}

1. Борисов Б. Г. Кружок радиотехнического конструирования. / Б.Г. Борисов - М.: Просвещение, 1986. -208 c.

2. Бойко М. П. Фізико-технічна творчість учнів. /М.П. Бойко, Є.Ф. Венгер, О.В. Мельничук. - Київ.: Вища шк., 2007. - 262 c.

3. Гончаренко C. Український педагогічний словник / С. Гончаренко - Київ.: Либідь, 1997. - 376 с.

4. Кабардин О. Ф. Внеурочная работа по физике / О.Ф. Кабардин, Э.М. Браверман, Г.Р. Глущенко и др.// Под ред. О.Ф. Кабардина. - М.: Просвещение, 1983. $223 \mathrm{c}$.

5. Кононенко С.О. Удосконалення методики організації та змісту гурткової роботи з радіоелектроніки друк. / С.О. Кононенко, О.В. Копчук, Д.В. Гринь // Наукові записки. Серія: Педагогічні науки. - Випуск 173. частина 2. - Кіровоград: РВВ КДПУ ім. Винниченка, 2018. - C. 123-127.

6. Манойленко Н. В. Особливості методики формування творчих вмінь майбутніх вчителів технологій / Н.В. Манойленко // Наукові записки. Серія: Проблеми методики фізико-математичної і технологічної освіти. Випуск 7. - Частина 1. - Кіровоград, РВВ КДПУ ім. В.Винниченка, 2015. - С. 85-88.

7. Скрябинський Б.С. Радіоелектроніка для юних. / Б.С. Скрябинський - Київ.: Веселка, 1985. - 205 с.

8. Черняшевський В.Т. Юному фізику. В.Т. Черняшевський - Київ.: Рад. шк., 1986. - 109 с.

\section{REFERENCES}

1. Borysov, B.H. (1986) Kruzhok radiotekhnichnoho konstruyuvannya. [Circle of radio engineering] Moscow.

2. Boyko, M.P., Venher, YE.F., Melnychuk, O.V. (2007) Fizyko-tekhnichna tvorchist uchniv. [Physical and technical creativity of students] Kyiv.

3. Honcharenko, S. (1997) Ukrayinskyi pedahohichnyi 
slovnyk. [UkrainianPedagogicalDictionary.] Kyiv.

4. Kabardyn, O.F., Braverman, E.M. Hlushchenko, H.R. and others. Vneurochnaya robota po fizytsi. [Extra-curricular work in physics ] Moscow.

5. Kononenko, S.O., Kopchuk, O.V., Grin, D.V. Udoskonalenya metodyky organizatsii ta zmistu gurtovoi roboty $z$ radioelektroniky druk. [Improvement of the methods of organization and content of the circle work on radio electronics printing.] Kirovohrad.

6. Manoylenko, N.V. Osoblyvosti metodiki formirovaniya tvorcheh vmin maybutnih vchyteliv tehnologiy. [Features of the method of formation of creative skills of future technology teachers] Kirovohrad.

7. Skryabinskyi, B.S. Radioelektronika dlya yunykh. [Radio electronics for young people.] Kyiv.

8. Chernyashevskyi, V.T. Yunomu fizyku. [Young physicist.] Kyiv.

\section{ВІДОМОСТІ ПРО АВТОРІВ}

КОНОНЕНКО Сергій Олексійович - кандидат педагогічних наук, доцент, доцент кафедри теорії та методики технологічної підготовки, охорони праці та безпеки життєдіяльності Центральноукраїнського державного педагогічного університету імені Володимира Винниченка.

Наукові інтереси: теорія та методика навчання (фізика та технологій).

МАНОЙЛЕНКО

Наталія

Володимирівна- кандидат педагогічних наук, доцент, старший викладач кафедри теорії i методики технологічної підготовки, охорони праці та безпеки життєдіяльності Центральноукраїнського державного педагогічного університету імені Володимира Винниченка.

Наукові інтереси: проблеми методики навчання технологій вищої школи.

\section{INFORMATION ABOUT THE AUTHOR}

KONONENKO Sergey Alekseevich - candidate of pedagogical sciences, docent, docent of department of theory and method of technological preparation, labour and safety of vital functions protection, professor of department of physics and method of its teaching of the Volodymyr Vynnychenko Central Ukrainian State Pedagogical University.

Circle of research interests: theory and methodology of teaching (physics and labor training).

MANOYLENKO Natalya Vladimirovna - candidate of pedagogical sciences, senior lecturer of the department of theory and methodology of technological training, health and safety and method of its teaching of the Volodymyr Vynnychenko Central Ukrainian State Pedagogical University.

Circle of research interests: problems of methods of teaching technology high school.

Стаття надійшла до редакиії 08.11.2019 p.

КУЗАН Галина Степанівна кандидат філологічних наук, доцент кафедри іноземних мов Національного університету «Львівська політехніка» ORCID:https://orcid.org/0000-0002-8050-9581 e-mail: g.kuzan@gmail.com

МАТВЇ̈в-ЛОЗИНСЬКА Юлія Олександрівна кандидат педагогічних наук, доцент кафедри іноземних мов Національного університету «Львівська політехніка» ORCID:https://orcid.org/0000-0002-6726-2537 e-mail: lozynskajuliya@yahoo.com

\section{ВИКОРИСТАННЯ МАТЕРІАЛІВ ЛЕКЦІЙ ТЕD ТАLКS ДЛЯ ПІДВИЩЕННЯ КОМУНІКАТИВНОЇ КОМПЕТЕНТНОСТІ СТУДЕНТІВ ЗАКЛАДІВ ВИЩОЇ ОСВІТИ}

Постановка та обгрунтування актуальності проблеми. На сьогоднішній день використання онлайн автентичних матеріалів на заняттях у закладах вищої освіти набуває постійного характеру. Це зумовлено не лише актуальністю пропонованої тематики, але і зручним способом використання як для студентів, так і для науково-педагогічного персоналу. Вміти застосовувати інформаційні технології у поєднанні 3 вивченням певної дисципліни є запорукою професіоналізму викладача та наявності мотивації та інтересу у студентів до предмету вивчення, формування висококваліфікованого майбутнього фахівця та успішної особистості.

Однією з популярних на сьогоднішній день онлайн ресурсів є платформа «TED Talks» - короткі лекції учасників щорічної конференції TED Technology, Entertainment, Design. Ці три напрямки були основними в часи заснування TED (1984).
Основне 3 гасел даного ресурсу ideasworthspreading, саме для тих, хто бажає розвиватись. Кожен виступ (лекція) на конференції TED називається «TEDTalk».

Відеозаписи публікуються на сайті www.ted.com, доступні безкоштовно для перегляду i скачування, також доступні на сайті YouTube. Для пристроїв iPhone i Androidдоступні як офіційні, так i неофіційні додатки, що дозволяють проглядати відеозаписи виступів з субтитрами, слухати радіо TED та інше. В кінці 2013 в рамках проекту «TEDOpenTranslationProject» офіційний додаток перекладено на різні мови, включаючи українську.

Зміст TED talks відповідає загальним компетенціям CEFR (Загальноєвропейські рекомендації з мовної освіти) у межах знань про світ, міжкультурної взаємодії та здатності навчатись. Даний ресурс безумовно зацікавить (www.ted.com), адже він надзвичайно зручний для 